\title{
Books, Gold and Elixir: Alchemy and Religious Orders in Early Modern Naples
}

\author{
Lorenza Gianfrancesco
}

School of Humanities, University of Chichester, United Kingdom

Department of History and Politics,

College Lane,

University of Chichester,

Chichester, PO19 6PE

Email: 1.gianfrancesco@chi.ac.uk

\begin{abstract}
During the early modern period Naples was a European centre of learning where a number of scholars engaged with alchemy. Variously perceived as a legitimate scientific practice or as a mendacious trick for gullible minds, alchemy engaged Neapolitan scholars in a dispute that involved members of the clergy. In this article I look at convents as research centres mainly engaged with medical alchemy. Specifically, I reconstruct the activity of the Dominican friar Tommaso d'Eremita. Upon his arrival at the Neapolitan convent of Santa Caterina a Formello in 1609 , d'Eremita set up a laboratory where he spent years working on alchemical procedures in order to produce an elixir of life for the benefit of all. Beyond this charitable mission, I also argue that members of religious orders in Naples engaged with alchemy for different purposes. In so doing, I discuss the cases of some members of religious orders in Naples who practised chrysopoeia with the aim of producing artificial noble metals.
\end{abstract}

\section{Introduction}


On 5 February 1640, the Franciscan father Crisanto of Naples "spontaneously appeared before the General Inquisitor." He alleged that a fellow friar, whom he identified as Pietro, "possessed a powder which he had used many times." That powerful substance, explained the Franciscan friar, "sent Pietro into ecstasy thus leaving him unconscious." Crisanto also confessed that other friars living in a convent located in the outskirts of Naples "had made use of that ecstatic powder." "2 Although Crisanto did not reveal the powder's composition to the Inquisitor, it is possible that it may have been made from mandrake roots: a powerful drug that was widely used in conventual apothecary shops. Father Crisanto's testimony also sheds light on forbidden practices in seventeenth-century Neapolitan religious houses. The use of what appears to be a powdered hallucinogen raises questions about the production of substances prepared in laboratories involved in alchemical experimentation and the manner in which they circulated within the enclosed spaces of religious communities.

This essay analyses the development of alchemical practices among religious orders in seventeenth-century Naples. First, it briefly discusses the professional organisation and the role of apothecaries in the populous city of Naples. It then looks at medical laboratories and the role of conventual apothecary shops in catering for the medical needs of Neapolitans, especially the poor. Furthermore, this essay discusses the role of some laboratories based in religious houses as gathering places where friars met with philosophers, literati and academicians. Participating in a wider debate on science and medicine, some members of religious orders set up libraries and laboratories, enlarged their network beyond the enclosed spaces of convents and often engaged in various forms of scientific experimentation. By presenting some case studies, this essay also highlights the different ways in which members

\footnotetext{
${ }^{1}$ Trinity College Dublin (hereafter TCD), Ms 1261, Records of the Roman Inquisition, fol. $597^{\mathrm{r}}$. ${ }^{2} \mathrm{TCD}$, Records of the Roman Inquisition, $598^{\mathrm{r}}-599^{\mathrm{v}}$.
} 
of religious orders in Naples perceived and experimented with alchemy. Some friars practised alchemy to achieve chrysopoeia. Others applied it to medical research often combining a traditional Galenic approach with innovations brought by the advancement of chemical medicine and its associated laboratory procedures. In this context, we shall see that both affluent private houses and enclosed convents became venues for forms of experimentation that in some cases pushed the boundaries of Catholic orthodoxy.

\section{The world of apothecaries in early modern Naples}

During the seventeenth century, Naples was a multicultural city and a major Mediterranean port. Capital of a kingdom under Spanish rule, Naples was also one of the largest cities in Europe with over 400,000 inhabitants in $1630 .^{3}$ As a trade centre, the port of Naples was bustling with cargo ships exporting a variety of materials and substances which included coral, metals, minerals and tartaric acid. ${ }^{4}$ Similarly, international cargo ships brought a variety of goods to Naples thereby fulfilling the market demands of the city's population. In addition, minerals and metals such as lead and tin, as well as plants and spices from the New World were also in demand for the preparation of medical recipes that "the apothecary must have in his shop."

3 National Library of Spain (hereafter BNE), Mss 10342, Francesco Zazzera, Giornali Dell'Illus.mo, et Ecc.mo Sigr. D. Pietro Girone Duca d'Ossuna nel Felice Governo di questo Regno di Napoli. Scritti da Francesco Zazzera Napolitano, Academico Otioso, vol. 1, 160". ${ }^{4}$ Giulio Cesare Capaccio, Descrizione Di Napoli Ne' Principii Del Secolo XVII. Edita a cura della Società di Storia Patria con prefazione di Bartolomeo Capasso (Naples: Giannini,1882), 45, Francesco De Pietri, Dell'Historia Napoletana (Naples: Domenico Montanaro, 1634); 26.

${ }^{5}$ A list of medical substances brought to Naples from the New World is in Carlo Pignataro, Petitorium. In Quo Continentur Ea, Quae quilibet Pharmacopoeus in sua Officina, in hac Urbe Neapoli, \& Regno, in Visitationibus faciendis habere, \& ostendere debet (Naples: Salvatore Castaldo, 1684), Introduction. 
Apothecary shops were located in various areas of the city centre and were often sited near major hospitals. They sold legally-approved medical remedies such as mixtures, ointments, and cataplasms as well as "all sorts of poisons, arsenic, opium, silver and other forbidden items." ${ }^{, 6}$ In order to prevent the illegal selling of poisonous substances in apothecary shops, between 1581 and 1589 state authorities issued a series of regulations banning apothecaries from selling their products to both untrained apothecaries and people without a medical prescription. The apothecary had to retain these prescriptions, so that he could make them available for state inspections. ${ }^{7}$

In May 1615, the city's guild of apothecaries and druggists renewed their charter and founded a charitable organisation for the relief of Naples' poor. The guild's new statutes were also intended to control the proliferation of charlatans selling "illegal mixtures and medicinal recipes" on the city's streets. To protect the guild's professional integrity and stop unscrupulous apothecaries from selling poisonous substances, state authorities also intervened by implementing their right to inspect apothecary shops. Moreover, state authorities established that apothecaries accused of fraud "would have their products burnt outside their shops" with the risk of being imprisoned and banned from the guild. ${ }^{8}$ In 1617 , the state issued another law against offences committed by apothecaries and doctors. It specified that "apothecaries be banned from dispatching to patients prescriptions which had not been signed by a trained doctor". Those who committed such unlawful practices were to be severely sentenced to "five years on the galleys for both apothecaries and doctors". 9 The guild, which possibly had Saint Aspren as its protector, was attached to the church of San

\footnotetext{
6 "De Pharmacopolis et Aromatariis" in Nuova Collezione delle Prammatiche del Regno di Napoli (Naples: Stamperia Simoniana, 1805), vol. 12, 201.

7 "De Pharmacopolis et Aromatariis," 205.

${ }^{8}$ State Archive Naples (hereafter ASN), B 1196/7, Cappellano Maggiore, "Droghieri e Speziali," 2r $4 \mathrm{v}$.

9 “De Pharmacopolis et Aromatariis," 207.
} 
Pietro in Vinculis where some of its meetings were held. ${ }^{10}$ In order to secure support from ecclesiastical authorities, the guild of apothecaries acted as a charitable institution with funds allocated to the maintenance of sacred buildings.

Despite these measures, charlatans and unlawful practitioners remained active in the city. A few years later, in 1640, state health authorities and the city's chief medical inspectorknown as the Protomedico- commissioned doctor Giuseppe Donzelli to write a book of medical recipes to be officially adopted by all apothecaries active in the Kingdom of Naples, including those belonging to religious orders. ${ }^{11}$ In compiling his list of remedies, Donzelli drew upon a corpus of ancient writers which included Aristotle, Galen, Hippocrates, Avicenna and the principles for the preparation of medicines set out by Mesue (Yuhanna ibn Masawaih). ${ }^{12}$ Donzelli also discussed the ethical standards pertaining to the profession. Addressing his thoughts to "ruling princes", he urged them to exercise caution when appointing apothecaries for their unscrupulous conduct and ignorance "may cause irreparable damage and death to the public". ${ }^{13}$ A trained medical apothecary, Donzelli explained, first had to apply himself to the study of simples, minerals, metals and stones and then work for six years under the supervision of a senior professional. ${ }^{14}$ Reacting against unlawful practitioners, Donzelli defined the perfect apothecary as one who refrains from administering "poisonous, expired or fake medicinal substances". ${ }^{15}$ The apothecary's knowledge and ethics were also rooted within a religious tradition that highlighted the role of the Church in the history of the profession. In stressing the "ethical mission" of diligent apothecaries, Donzelli

\footnotetext{
${ }^{10}$ ASN, B 1196/7, Cappellano Maggiore, "Droghieri e Speziali," 1630, $2^{\mathrm{r}}$. See also Luca Chichierchia and Simona Papa, Storia della farmacia a Napoli. Dalla "Spetiaria” conventuale alle botteghe dell'Ottocento (Naples: Electa, 1998), 19- 24.

${ }^{11}$ Giuseppe Donzelli, Antidotario Napolitano (Naples: Francesco Savio, 1642).

${ }^{12}$ Giuseppe Donzelli, Petitorio Napolitano (Naples: Novello de Bonis, 1663), 30-31.

${ }^{13}$ Donzelli, Petitorio, 6.

${ }^{14}$ Donzelli, Petitorio, 16.

${ }^{15}$ Donzelli, Petitorio, 5.
} 
referred to a number of holy figures who had mastered that profession. Indeed, since early Christianity "many Saints had prepared medical remedies with their own hands". Saint Paul, Saint Mary Magdalene, Saint Ambrose, Saint John Chrysostom and Saint Justina were just some of the holy figures who were remembered for their ointments, mixtures, medicinal oils and electuaries. $^{16}$

Referring to his own time, Donzelli also highlighted the role of religious orders in producing medicinal recipes. For instance, he mentioned the Benedictine friars of Naples as dispensers of an oil against parasitic worms. ${ }^{17}$ In describing the preparation of an ointment, Donzelli also praised the method developed by the Dominican friar Cataldo della Cava, who was the apothecary in the convent of Santa Maria della Sanità. ${ }^{18}$ In his capacity as medical inspector, Donzelli visited laboratories and pharmacies located in various Neapolitan convents. In some cases, he also assisted in the production of certain medical remedies produced by friars, and approved others. This is attested by the dedicatory verses written by the Calabrian friar Biagio Bonelli and contained in Donzelli's Theatro Farmaceutico (1675). Bonelli worked as an apothecary in the Carthusian convent of San Martino in Naples. ${ }^{19}$ Praising Donzelli for having assisted him in the preparation of a theriac in his convent, Bonelli's verses also referred to a conversation during which Donzelli "brilliantly explained the occult properties and the essence of that great compound that frees the world from any kind of poisoning". ${ }^{20}$ In a similar vein, in 1678 Bonelli wrote dedicatory verses to Francesco

\footnotetext{
${ }^{16}$ Donzelli, Petitorio, 11-12.

${ }^{17}$ Donzelli, Petitorio, 12.

${ }^{18}$ Donzelli, Petitorio, 244.

${ }^{19}$ A history of the apothecary shop in the Neapolitan convent of San Martino can be found in Rossana Muzii and Rita Pastorelli, eds., La spezieria. La farmacia monumentale dei monaci certosini (Naples: Electa, 2005), 25-32.

${ }^{20}$ Giuseppe Donzelli, Teatro Farmaceutico, Dogmatico e Spagirico (Naples: Francesco Paci, Geronimo Fasulo, e Michele Monaco, 1675), Preface. A short biographical entry on Biagio Bonelli is in Niccolo Toppi, Biblioteca Napoletana (Naples: Antonio Bulifon, 1678), 49. On the production of
} 
Maria Massari in the latter's manual on chemistry which was published in Naples. In his verses, the Calabrian friar praised Massari for the publication of a practical text whose aim was to instruct physicians, apothecaries and surgeons on how to learn chemistry. ${ }^{21}$

The contents of Bonelli's verses indicate that members of religious orders in Naples were recognised as professional apothecaries. As discussed by Peter Murray Jones elsewhere in this issue, they operated within a tradition dating back to the Middle Ages. Donzelli's support of medical research conducted in convents also indicates that state authorities considered medical recipes produced in religious houses to be ethically prepared and thus of good quality. Moreover, in exercising their profession within the secluded spaces of convents, friar-apothecaries were believed to be removed from the illegal trade of fake remedies and poisonous substances. This reputation as purveyors of reliable medicaments set them apart from certain owners of apothecary shops situated in various city districts who were often accused of selling forbidden medical substances. ${ }^{22}$

\section{Mapping the geography of Neapolitan conventual apothecary shops}

During the early modern period, Naples was home to some 200 churches and fifty-four convents. ${ }^{23}$ In line with their charitable mission, a number of religious orders in the city catered for the spiritual and medical needs of a large segment of Neapolitans living in poverty. Some religious institutions had shops and laboratories where friars worked as

theriac in early modern Italy see Valentina Pugliano, "Pharmacy, testing, and the language of truth in Renaissance Italy," Bulletin of the History of Medicine 92 (2017): 266-72.

${ }^{21}$ Francesco Maria Massari, Prattica Chimica (Naples: Antonino Gramignani, 1678), Preface.

${ }^{22}$ Donzelli, Petitorio Napolitano.

${ }^{23}$ A list of churches and convents is in Engenio Caracciolo, Napoli Sacra (Naples: Ottavio Beltrano, 1623); Domenico Antonio Parrino, Napoli. Città Nobilissima, Antica, e Fedelissima (Naples: Parrino, 1700); Giulio Cesare Capaccio, Il Forastiero (Naples: Giovanni Domenico Roncagliolo, 1634). 
speziali (apothecaries) to prepare medical recipes for the cure of fellow friars and members of the public. ${ }^{24}$ At the turn of the seventeenth century there were about twenty apothecary shops located in some of the city's convents. ${ }^{25}$ The largest and most important were managed by the Dominicans, Carmelites, Franciscans, Theatines and Jesuits. ${ }^{26}$ Religious houses also often hosted hospitals and infirmaries within their premises. An example was the convent attached to the church of Santa Maria La Nova which was home to the Franciscan Order of the Friars Observant, who also managed an infirmary and a shop selling medicines "for the cure of sick people". ${ }^{27}$ Moreover, the church of Santa Maria Annuntiata was attached to one of the city's largest hospitals. In its courtyard there was "a large and clean shop managed by an apothecary friar and five assistants". ${ }^{28}$ In some contemporary sources it is reported that the church spent "12,000 scudi to keep the shop well-stocked with all medicinal remedies for the hospital patients and staff as well as for the poor of Naples". ${ }^{29}$

What is more, the church of Santa Maria del Popolo was attached to a hospital and an apothecary shop that was "well equipped with a variety of simples and other necessary remedies". ${ }^{30}$ In the cloister annexed to the church of Santa Maria del Carmine there was also an apothecary shop managed by the Carmelite friars of Naples. ${ }^{31}$ In addition, the city's Jesuit College hosted "a most famous shop equipped with the rarest drugs from the West and East

\footnotetext{
${ }^{24}$ David Gentilcore argues that in early modern Naples there were 87 apothecary shops of which 18 were located in convents. See David Gentilcore, Healers and Healing in Early Modern Italy (Manchester: Manchester University Press, 1998), 15. For the role of nuns as apothecaries see Gianna Pomata, "Medicina delle monache: pratiche terapeutiche nei monasteri femminili di Bologna in età moderna" in Gianna Pomata and Gabriella Zarri, eds, I monasteri femminili come centri di cultura fra Rinascimento e Barocco (Rome: Edizioni di Storia e Letteratura, 2005), 331-63.

${ }^{25}$ A list of the conventual apothecary shops in Naples is in Chichierchia and Papa, Storia della farmacia a Napoli, 31-61.

${ }^{26}$ Parrino, Napoli. Città Nobilissima, vol. 1, 74-90.

${ }^{27}$ Caracciolo, Napoli Sacra, 485-99.

${ }^{28}$ Caracciolo, Napoli Sacra, 490.

${ }^{29}$ Caracciolo, Napoli Sacra, 398-404.

${ }^{30}$ Caracciolo, Napoli Sacra, 186.

${ }^{31}$ Caracciolo, Napoli Sacra, 437.
} 
Indies". ${ }^{32}$ At the beginning of the seventeenth century, the monastery of Santa Maria della Pace opened an apothecary shop which consisted of a large room where medicines were sold, and a smaller room hosting a laboratory equipped with "blades, presses, alembics and other pieces of necessary equipment". 33

Within the complex world of the Neapolitan religious orders, the most famous centre for the production of medical remedies was perhaps that situated in the Dominican convent of Santa Caterina a Formello. As we shall see shortly, the convent was also equipped with a laboratory where alchemy was performed. In his description of this religious house, the Neapolitan historian Engenio Caracciolo stated that Santa Caterina a Formello was worthy of praise both for "its most beautiful cloister and the important library which was instituted for the use of the seventy-nine Dominicans who live there". ${ }^{34}$ The library contained a pharmacopoeia to which the friars working in the convent's medical centre had access. ${ }^{35} \mathrm{~A}$ few decades later, Antonio Farina, a foreigner in Naples, visited Santa Caterina a Formello. In his travel account he wrote that next to the convent's church "there is a beautiful museum and an apothecary shop (spetiaria) full of curiosities, among which one can see natural monstrosities, and two mandrake roots: one male and one female which are worth seeing", ${ }^{36}$ In 1609 the convent rose to notoriety when a Dominican friar arrived in Naples from

\footnotetext{
${ }^{32}$ Parrino, Napoli. Città Nobilissima, vol. 1, 208. See also Daniela Caracciolo, Maurizio Di Gregorio. Le coselline di un ometto curioso. L'Idea di fare le gallerie universali di tutte le cose del mondo, naturali, artificiali e miste (Galatina: Congedo Editore, 2008), 41.

${ }^{33}$ In Chicherchia and Papa, Storia della farmacia a Napoli, 32: "lame, torchi, lambicchi e quant'altro occorresse".

${ }^{34}$ Chicherchia and Papa, Storia della farmacia a Napoli, 149.

${ }^{35}$ Carlo Celano also mentioned the existence of another important medical library which had been set up in the Neapolitan Dominican convent of Santa Maria alla Sanità in the 1570s by a certain friar Cataldo Caporeo. See Carlo Celano, Notitie del bello, dell'antico, e del curioso della Città di Napoli (Naples: Giacomo Raillard, 1692), 96-7.

${ }^{36}$ Antonio Farina, Compendio delle Cose piu Curiose di Napoli, e di Pozzuoli, con alcune notitie del Regno (Naples: ?, 1679), 36.
} 
Tuscany. His name was Donato d'Eremita and his base the medical centre of Santa Caterina a Formello.

\section{Donato d'Eremita's medical research at the convent of Santa Caterina a Formello}

Little is known about the Dominican friar Donato d'Eremita. Born in Rocca D'evandro, a village in northern Campania, Donato spent a period in Tuscany where he worked on spagyric remedies under the patronage of Duke Ferdinand II de Medici. ${ }^{37}$ In the preface to his Elixir vitae (Naples, 1624), which was dedicated to the duke, Donato praised Ferdinand "for funding the preparation of precious antidotes" and for supporting "a number of artificers and experts of the mysteries of the occult philosophy from whom I have learnt the skills to advance in this profession". ${ }^{38}$ The Elixir vitae was the only work published in the friar's lifetime. D'Eremita also wrote Antidotario, a text on the apothecary's art which was printed posthumously. In addition to these texts, he wrote further volumes on distillation and stones which survive in manuscript form. ${ }^{39}$ In Naples, d'Eremita acquired fame as "a most erudite figure and an expert in the production of healing remedies". ${ }^{40}$ In recognition of his expertise "in the chemical and herbal art", in 1611 the prefect of Santa Caterina a Formello decided to build a new area within the convent in order to allow the friar "to exercise his virtuous

\footnotetext{
${ }^{37}$ A brief biographical account on d'Eremita is in Jacobus Quetif \& Jacobus Echard, Scriptores Ordinis Praedicatorum Recensiti (Paris: Ballard, 1722), vol. 2, 433; Caracciolo, Le coselline, 41. ${ }^{38}$ Donato d'Eremita, Dell'Elixir Vitae (Naples: Secondino Roncagliolo, 1624), Preface and dedication. ${ }^{39}$ Donato d'Eremita Antidotario (Naples: Secondino Roncagliolo, 1639). A reference to d'Eremita's manuscript production is in Caracciolo, Coselline, 58.

${ }^{40}$ Pietro Castelli, De Abusu Exhibitionis medicamenti purgantis in Octavo die (Messina: Bonacota, 1659), 1; Pietro Castelli, Discorso della differenza tra gli semplici freschi et i secchi. Con il modo di seccarli (Rome: Giacomo Mascardi, 1629), 41.
} 
talent". ${ }^{41}$ There, d'Eremita was appointed as prefect of the convent's apothecary shop (aromatariae praefectus). ${ }^{42}$ In Santa Caterina, d'Eremita was also granted permission to set up a science museum and enlarge the convent's library which in 1629 listed "twenty-four plates from Della Porta's Phytognomonica and prints from Imperato's work". 43

Giambattista Della Porta and Ferrante Imperato were key figures within d'Eremita's Neapolitan network. His connection to these leading intellectuals is perhaps unsurprising. As authors of texts on alchemy, distillation, mineralogy and botany they had much in common with the Dominican friar. As we shall see, Imperato's Historia Naturale and some of Della Porta's works such as Magia Naturalis, De Phytognomonica and De distillatione partly inspired d'Eremita's Elixir. Moreover, as the dedicatory verses of both the Elixir and the Antidotario reveal, d'Eremita established contacts with a number of local academies including the Incauti which had been promoted by the Carmelite and Augustinian Orders of Naples. ${ }^{44}$ The friar's Neapolitan network which comprised literati, philosophers and practitioners like Della Porta was also instrumental in facilitating contacts within the Lincei academy of science. Founded in 1603 in Rome by Federico Cesi, the Lincei soon established an active base in Naples. ${ }^{45}$ In 1619 , d'Eremita went to Rome and met with the Lincean doctor

\footnotetext{
${ }^{41}$ Fra' Tomaso Renaldi, Dell'Historia chronologica del convento di Santa Catarina a Formello (1731), 213-14. This passage from Renaldi's Historia has been transcribed by Martino Canonico, «Fabrica del convento, e i suoi membri» in Santa Caterina a Formello. Vicende di un'insula napoletana (Naples: Electa, 1996), 108. See also Chichierchia and Papa, Storia della farmacia a Napoli, 52.

${ }^{42}$ Francisco Hernández, Rerum Medicarum Novae Hispaniae Thesaurus seu Plantarum Animalium Mineralium Mexicanorum Historia (Rome: Vitale Mascardi, 1651), 866.

${ }^{43}$ Letter from Fabio Colonna to Federico Cesi dated Naples, 30 November 1629 in Giuseppe Gabrieli, Memorie Della Reale Accademia Nazionale Dei Lincei. Il Carteggio Linceo della vecchia accademia di Federico Cesi (1603-1630), Serie VI, vol. 7, n.3 (Rome: Giovanni Bardi, 1938), 1205.

${ }^{44}$ Lorenza Gianfrancesco, From Propaganda to Science: Looking at the World of Academies in Early Seventeenth-Century Naples, California Italian Studies, vol. 3 no. 1, 2012, 9-10.

${ }^{45}$ Although a branch of the Lincei was never opened in Naples, Federico Cesi bestowed the affiliation upon a number of Neapolitan scholars including Giambattista Della Porta, Fabio Colonna and Nicola Antonio Stigliola. See Michele Maylender, Storia delle Accademie d'Italia (Bologna: Rava, 19261930), vol. 3, 430-60; David Freeberg, The Eye of the Lynx. Galileo, his Friends, and the Beginning of Modern Natural History (Chicago and London: Chicago University Press, 2002). For a comprehensive database of early modern Italian Academies see www.italianacademies.org. See also
} 
and botanist Johann Faber. During his stay in Rome, d'Eremita visited Cardinal Odoardo Farnese's botanical garden where he was able to admire an example of passiflora (passion flower). This plant had been brought to Italy from the New World and was known for its anaesthetic properties. On his return to Santa Caterina, d'Eremita commissioned a coloured engraving of the passiflora which he donated to Faber to thank him for the hospitality he had received in Rome. ${ }^{46}$ [See Figure 2, at end of document]

By 1622, the friar had grown this plant in Santa Caterina's herb garden. ${ }^{47}$ This is stated in a short dedication contained within the second known engraving of the passiflora that d'Eremita commissioned as a gift for the Neapolitan botanist and Lincean academician Fabio Colonna. ${ }^{48}$ [See Figure 1, at end of document]

In 1651, a few years after d'Eremita's death, the Lincean academy published Francisco Hernández's Rerum Medicarum Novae Hispaniae Thesaurus. ${ }^{49}$ Printed some sixty years after Hernández's death, this work analyses the medicinal virtues of plants, animals and minerals from the New World. In his annotations to the section devoted to botany, Colonna made several references to d'Eremita's expertise in that discipline. In referring to the rich herb garden that the friar had planted in Santa Caterina, Colonna also praised Donato's expertise on exotic botanical species, including the passiflora. D'Eremita choose the passiflora as his personal emblem because of this plant's healing properties and symbolic connotation of the Passion of Christ. [See Figure 7, at end of document]

Simone Testa, Italian Academies and their Network, 1525-1700. From Local to Global (New York: Palgrave Macmillan, 2015).

${ }^{46}$ Natural History Museum Library, London (hereafter NHML), SB 582.4P74.RAS.F.CAT. UNIT, Donato d'Eremita, Engravings of Passiflora, fol. 4.

${ }^{47}$ According to Chichierchia and Papa, the herb garden and the apothecary shop in Santa Caterina were instituted in 1611. See Chichierchia and Papa, Storia della farmacia a Napoli, 52.

${ }^{48}$ NHML, d'Eremita, Engravings of Passiflora, fol. 6.

${ }^{49}$ Francisco Hernández, Rerum Medicarum Novae Hispaniae Thesaurus (Rome: Vitale Mascardi, 1651). 
The Lincean edition of Hernández's work also contains a long section on animals from the New World with a commentary and annotations by Faber. In the chapters devoted to reptiles, Faber discussed the healing properties of theriac which he compared to other remedies used to expel venom from the human body. Interestingly, Faber made a reference to the medicinal properties of aqua vitae which, he noted, "Giambattista [Della] Porta clearly shows in his book on distillation". ${ }^{50}$ Here, Faber also referred to d'Eremita's book and his "chemically produced" elixir vitae which was prepared through a long laboratory process involving distillation. Faber praised d'Eremita's elixir for its healing properties and compared it to theriac which "if taken in a small quantity it animates our spirits so that in resisting venom, Herculean forces are regained". 51

The idea that a panacea could be chemically made through a laboratory procedure based on distillation is particularly relevant to our discussion. In his Magia Naturalis, Della Porta explained the process of distilling the quintessence of substances. This was achieved by separating the spiritual essence contained in the grossness of bodies. As Della Porta explained, "by chymical Instrument" the art of distillation "teacheth how to make Spirits, and sublime gross Bodies; and how to condense, and make Spirits become gross bodies: and to draw forth of Plants, Minerals, Stones and Jewels, the Strength of them, that are ... lying, as it were, in their Chests". ${ }^{52}$ Here, Della Porta drew on the principle of chemical separation and defined the quintessence as a spirit separated from all forms of impurity existing in the grossness of the elements. This process was at the core of Della Porta's method of producing the elixir of life. Defined as "the Conservators of Bodies [...] for their virtue is to preserve

\footnotetext{
${ }^{50}$ Hernández, Rerum Medicarum, 785. Here Faber refers to Giambattista Della Porta, De Distillatione (Rome: Typographia Rev. Camerae Apostolicae, 1608), 135-41.

${ }^{51}$ In Hernández, Rerum Medicarum, 787: "Nolo etiam nobilissimam illam compositionem, chymicè paratam, quam Elixir vitae appellant, sua laude fraudari, qua in minima quantitate haustà, spiritus nostri ita animantur, corroborantur, \& instaurantur, ut ad propugnanda, venena, Herculeis viribus insurgant."

${ }^{52}$ Giambattista Della Porta, Natural Magick, ,book 10, On Distillation (London: Printed for Thomas Young, and Samuel Speed, 1658), 254.
} 
from corruption", elixirs were "compounded of many things [...] to be dissolved or liquefied". ${ }^{53}$ A mixture of substances, they could only be produced in a laboratory through an alchemical process that involved sublimation, contrition, descension, ascension, extraction, maceration, calcination, heating and distillation.

The latter was the ultimate stage through which the essence of plants, metals, minerals and stones could be obtained. By extracting "the Spirit, being separated from the phlegm [...] [and] run invisible into the Receiver", distillation allowed matter to reach its purest state and thus its highest medical effectiveness. ${ }^{54}$ This principle was at the core of a research method that Della Porta also discussed in De distillatione. ${ }^{55}$ Here, the Neapolitan scholar listed three kinds of elixir: "The first made with metals such as gold, silver, other minerals such as sulphur, arsenic, salt, chalcanthite. and potassium nitrate. The second is made of gems...the third of plants." ${ }^{, 56}$ Moreover, in presenting a wider range of elixirs to be produced in a laboratory, Della Porta highlighted the efficacy of metals and minerals in medical research. In so doing, he also acknowledged the significance of Paracelsian medicine which he merged within the Aristotelian and Galenic tradition. The principles discussed by Della Porta in both the Magia Naturalis and De distillatione shaped a new programme of empirical research that reached the busy world of Neapolitan conventual laboratories.

D'Eremita had been conducting experiments to perfect his panacea in Santa Caterina a Formello since 1610. When the results of his research were published in 1624, Neapolitan scholars welcomed the friar's book as a further recognition of Naples as a centre for scientific research. In the city where, as Della Porta had written to Cesi, "the philosophers' stone is

\footnotetext{
${ }^{53}$ Della Porta, Natural Magick, 274.

${ }^{54}$ Della Porta, Natural Magick, 257.

${ }_{55}$ Giambattista Della Porta, De Distillatione.

${ }^{56}$ In Della Porta, De Distillatione, 136-37: "Prima metallica, ut auri, argenti, et caeterorum Mineraliu[m], ut Sulphuris, Arsenici, Salis, Chalcanthi, \& Halinitri. Secunda gemmarum...tertia plantarum."
} 
being produced in many places", a universal antidote had finally been manufactured. ${ }^{57}$ The dedicatory verses contained in the Elixir were also a recognition of the friar's importance within the city's academic milieu. ${ }^{58}$ As d'Eremita stated in his book, he had shared his laboratory research with a number of "most excellent philosophers and doctors". In the third chapter of the Elixir, for instance, the Dominican friar recounted that he had invited Giambattista Della Porta, Nicola Antonio Stigliola and Vincenzo Forte (spagyric to Philip IV of Spain) and others to his laboratory. Here, d'Eremita showed them the properties of his elixir which "is widely used by scholars and excellent doctors to heal all kinds of disease". 59

In presenting to the reader the properties of his prodigious medicine, d'Eremita showed a deep knowledge of alchemical terminology. Interestingly, he variously named his medical remedy as "Celestial water, the star of Diana, quintessence, celestial power of spirit, soul and Aether." D'Eremita also defined his elixir as "vegetable Mercury, the gold costume of a youth, a marriage of the male and female that gives birth to a new life and the philosopher's key that opens the way for the elixir to penetrate and heal the human body". 60 Through a complex laboratory procedure aimed at purifying substances in order to extract their healing properties, d'Eremita conceived alchemy as a tool through which it was possible to merge botanical knowledge with the study of chemicals and minerals for medical purposes. As I shall discuss in the next section, the friar's knowledge of alchemical practices played a central role in the preparation of his universal medicine.

\section{Searching for the essence: the making of the elixir of life}

\footnotetext{
${ }^{57}$ Della Porta's letter to the President of the Lincean academy is dated 16 December 1612. A transcription is in Baldassare Odescalchi, Memorie Istorico Critiche dell'Accademia De' Lincei (Rome: Luigi Perego Salvioni, 1806), 111.

${ }^{58}$ D'Eremita, Elixir Vitae, Preface. Dedicatory verses praising the museum that d'Eremita had set up in Santa Caterina are also contained in d'Eremita, Antidotario, Preface.

${ }^{59}$ D'Eremita, Elixir Vitae, 4.

${ }^{60}$ D'Eremita, Elixir Vitae, 5-7.
} 
In the opening chapter of his book, d'Eremita informed the reader of both the function and composition of his medicine. A powerful mixture of "stones, minerals, herbs, plants and other similar things", the elixir was, the friar claimed, also intended to help people fulfil their desire for self-preservation. ${ }^{61}$ To acquire the medical knowledge required for such an endeavour, d'Eremita relied upon a large corpus of source material. This ranged from the writings of Galen to those of Paracelsus and, more recently, those of Imperato and Della Porta. In explaining the healing properties of his aqua vitae (the base of the elixir), d'Eremita incorporated Arnald of Villanova's treatise on wine and "Theophrastus" discussion on the virtues of this substance. He also looked at "Jean de Roquetaillade's Liber de consideratione quintae essentiae [...] and many others who have written that quintessence of wine has wonderful effects to cure all diseases". ${ }^{62}$ Believed to be one of the most powerful medical substances in nature, quintessence could only be produced through artificial extraction. Here d'Eremita distanced himself from the method used by traditional semplicisti (herbalists) "who make use of the curative properties of plants by extracting their essence and preparing decoctions". ${ }^{63}$ Instead, he took inspiration from Della Porta's work and considered distillation to be the most effective method to extract quintessence "which is a living spirit and an invisible virtue that resides in natural substances [...] but that reaches its highest degree of medical effectiveness in wine". ${ }^{64}$ Drawing upon Aristotle and Mesue's principle of a cosmological influence "between the Heavens and the Earth", d'Eremita believed that the occult properties of substances existed as "an act of love of the Heavens infusing their own virtues in nature". It was through a laboratory procedure that d'Eremita deemed it possible to

\footnotetext{
${ }^{61}$ D'Eremita, Elixir Vitae, 2.

${ }^{62}$ D'Eremita, Elixir Vitae, 25. See also Peter Murray Jones's reference to Roquetaillade in this issue.

${ }^{63}$ D'Eremita, Elixir Vitae, .7.

${ }^{64}$ Idem.
} 
extract the occult properties of natural substances and the healing power they carried. ${ }^{65}$ Distillation played a central role in this process for it enabled transmutation to reach its highest degree of purity. In this context, d'Eremita's ideas were, in a way, similar to Paracelsian alchemy. ${ }^{66}$ In explaining the process of extracting aqua vitae, d'Eremita gave an account of the different methods other scholars had used to practise distillation. Here, for instance, he referred to Christopher of Paris, Girolamo Cardano, Arnald of Villanova Nova, Jean de Roquetaillade and "many other chemist authors who have used distillation to produce medical remedies". ${ }^{67}$ D'Eremita devoted a long section of his Elixir to an examination of the various stages of distillation. He even asserted that through this laboratory process human intervention could supersede nature. This was possible, d'Eremita explained, as "the artificial heat of distillation enables the practitioner to separate the grossness from the essence in shorter time. Purification is then achieved by extracting a specific form, which is almost divine, and its virtues". ${ }^{68}$ To perfect the healing properties of quintessence, d'Eremita also believed that it was necessary to extract the saline active substance contained in aqua vitae. ${ }^{69}$ Moreover, the friar claimed to have found a method "to make aqua vitae able to dissolve not only simples but also calcined gold and silver so as to reduce them to oil". This was, he added, achievable only by modifying the stages of the distillation process.

Stating that the traditional process of "repeated distillation" delayed the extraction of quintessence, d'Eremita claimed to have found a "cheaper, easier, quicker and more efficient method to produce aqua vitae ${ }^{70}$ Here the friar explained that he had originally equipped his laboratory with five alembics (each with their own degrees of heat) used in the distillation

\footnotetext{
${ }^{65}$ D'Eremita, Elixir Vitae, 8-9.

${ }^{66}$ Bruce T. Moran, Distilling Knowledge. Alchemy, Chemistry, and the Scientific Revolution (Cambridge and London: Harvard University Press, 2005), 70-6.

${ }^{67}$ D'Eremita, Elixir Vitae, 14.

${ }^{68}$ D'Eremita, Elixir Vitae, 12.

${ }^{69}$ D'Eremita, Elixir Vitae, 15.

${ }^{70}$ Idem
} 
process. In order to perfect the process of purifying aqua vitae, d'Eremita claimed to have invented a laboratory device containing a sixth alembic "which is considered to be more noble ... and easier to use". ${ }^{71}$ [See Figure 6, vessel $\mathrm{H}$ at end of document] The sixth alembic, d'Eremita explained, "will allow a moderate passage of the vaporous spirit so that its most perfect and purest part will transcend in the last recipient $\mathrm{H}$, and distilled just once [...] this method has been personally put in place and it has proved to be the easiest, the shortest and the cheapest for our work and for any other work that the artificer may wish to carry out in order to produce the perfect aqua vita."72 The crystalline water produced through this perfected distillation process had the power to extract the occult virtues of plants, minerals or indeed any other natural substance. ${ }^{73}$ Drawing from Aristotle's principle that within each category of elements in nature only one carries perfection, d'Eremita defined his elixir as perfect, pure, incorruptible and indissoluble, and hence a remedy "that supersedes all medicines produced for the preservation of the body". ${ }^{74}$ D'Eremita believed that his Elixir embraced within itself an untouchable and invisible ethereal spirit. Through a process of separation, reunification, purification, and finally distillation, a sublimated essence "is made to appear as a liquid that ... in antipathy with a diseased humour it drives it away like an enemy.",75

Vases, alembics, retorts and furnaces: the iconography of d'Eremita's laboratory

\footnotetext{
${ }^{71}$ D'Eremita, Elixir Vitae, 19.

${ }^{72}$ D'Eremita, Elixir Vitae, 20.

${ }^{73}$ D'Eremita, Elixir Vitae, 22.

${ }^{74}$ D'Eremita, Elixir Vitae, 23.

${ }^{75}$ D'Eremita, Elixir Vitae, 24-5.
} 
Besides d'Eremita's discussion of a perfected distillation process, perhaps the best record of the friar's engagement with alchemy is provided by the iconographical section contained in the Elixir. After having presented the properties of his medicine and the method used to produce it, d'Eremita accompanied his text with a series of images representing the furnaces, vessels, and alembics displayed in his conventual laboratory so that "one can see the number and type of vases used for distillation." In the first image a room with books and a table displaying a number of plates form the background to a scene in which d'Eremita, wearing his Dominican habit, shows three luted alembics to a group of visitors. Behind two figures wearing ancient clothes (a possible reference to d'Eremita's reverence for ancient scientific models) appears Giambattista Della Porta, amongst other unidentified contemporaries. The scene is framed with representations of alembics, retorts, vases, furnaces, a tower and a frontal image of an enthroned Madonna with child. [See Figure 3, at end of document]

The rich iconography contained in the Elixir also includes the description of a furnace with a long vessel holding five communicating alembics attached to a sixth long alembic that the friar claimed to have invented. [See Figure 6 vessel $\mathrm{H}$, at end of document]

Interestingly, the rich ornaments that frame the images of d'Eremita's laboratory equipment bear resemblance to some frescoes and paintings commissioned by the Dominicans of Naples for the decoration of two important rooms in Santa Caterina a Formello. During d'Eremita's time at the Neapolitan convent, the apothecary shop did good business. In 1619, the profits generated from the selling of medicines funded the extension of the convent's laboratory at the back of the apothecary shop. ${ }^{76}$ In addition, both the apothecary shop and its storage room were embellished with paintings and frescoes. In the room where medicines were stored the Dominican friars commissioned a painting of the Virgin. The shop was also adorned with frescoes of flowers, arabesques and varieties of fruit enriched with

\footnotetext{
${ }^{76}$ Chichierchia and Papa, Storia della farmacia a Napoli, 53.
} 
cornucopias and golden motifs. ${ }^{77}$ These details seem to be reproduced in the frames surrounding the plates contained in the Elixir. ${ }^{78}$ Hence it is fair to suggest that d'Eremita probably wished to include in his books some of the artistic features of the rooms where he spent the most important period of his life. Some of the plates in the Elixir also contain the friar's personal emblem: a cartouche representing a hand holding a passiflora and framed with d'Eremita's name. [See Figure 7, at end of document]

As Tara Nummedal has argued, images of early modern alchemical laboratories should be seen as imagined rather than realistic representations of the spaces in which alchemists worked. ${ }^{79}$ The images contained in d'Eremita's Elixir offer the material to reflect upon "the space of alchemy" in religious houses and the ideological function of illustrations. Whether realistic or fanciful, these images offer a glimpse into the world in which the friar worked and networked. In that sense, the type of images contained in d'Eremita's book challenge the idea that early modern European alchemical laboratories were secretive spaces. ${ }^{80}$ On the contrary, the images contained in the Elixir can be interpreted both as a form of self-visibility and as an ideological statement of the role of Neapolitan religious orders as research centres that operated in dialogue with the city's milieu and thus participated in the dissemination of scientific knowledge. Moreover, the image that represents d'Eremita as a Dominican, a practitioner and a member of the Neapolitan intellectual elite showing his panacea to a group of male scholars, including Della Porta, can also be interpreted as a statement portraying religious orders as receptive rather than enclosed communities which encouraged erudite friars to conduct research whilst opening the doors of convents to philosophers, practitioners and academicians. The plates of passiflora that d'Eremita

\footnotetext{
${ }^{77}$ Chichierchia and Papa, Storia della farmacia a Napoli, 54.

${ }^{78}$ See Figures 4, 5, and 6, at the end of document.

${ }^{79}$ Tara Nummedal, Alchemy and Authority in the Holy Roman Empire (Chicago and London: The University of Chicago Press, 2014), 119-122.

${ }^{80}$ Nummedal, Alchemy and Authority, 120.
} 
commissioned for Colonna and Faber can also be read as a visual testimony to the friar's network. Moreover, the rituals of sociability that developed around the activities of some Neapolitan conventual laboratories mirrored similar practices that occurred in apothecary shops based in other Italian cities. As Filippo de Vivo has recently shown, early modern Venetian apothecary shops became gathering centres for the propagation of news, political communication and religious dissent. In that sense, the group that gathered in d'Eremita's laboratory were part of a network that, although focussed on the propagation of scientific knowledge, fostered communication between the clergy and the laity. Consequently, this allowed for a degree of intellectual inclusiveness which was also reflected in the visual representation of d'Eremita's circle. ${ }^{81}$

In 1630, the prior of Santa Caterina a Formello discontinued the financial support previously provided to the conventual laboratory where d'Eremita conducted his research. As the support granted by the prior to D'Eremita's studies had been raised from the selling of medicines, the friar fiercely opposed the prior's decision and claimed he was entitled to some of the convent's profits that had been generated thanks to his work and research. According to the account contained in Tomaso Renaldi's manuscript history of the Neapolitan convent, the prior then ordered that d'Eremita be locked in the conventual hospital. ${ }^{82}$ The following morning the Dominican friar was found dead. He had committed suicide by ingesting a lethal substance. Following d'Eremita's death, the convent's prior appointed friar Francesco Milano as rector of the convent apothecary shop. A few years later, Renaldi recounted, the friar escaped from Santa Caterina with a large sum of money raised from the selling of

\footnotetext{
${ }^{81}$ Filippo de Vivo, "Pharmacies as Centres of Communication in Early Modern Venice" Renaissance Studies,. 21, (2007), 511-17.

${ }^{82}$ A transcription of passages from Tomaso Renaldi's Dell'Historia is in Chichierchia and Pace, Storia della farmacia a Napoli, 54.
} 
medicines. ${ }^{83}$ Milano was not the only unscrupulous friar to have deviated from the religious values of those who, like Donato d'Eremita, had spent their life serving God and the community.

\section{Pushing boundaries: religious orders and forbidden alchemy}

Although a number of friars practised alchemy for medical purposes in early modern Naples their activities were viewed with hostility by different groups within the clergy. Their concerned were not unfounded. As I shall discuss in the next pages, for some members of religious orders in Naples alchemy was a tool to achieve aims that did not necessarily conform to religious orthodoxy or indeed secular law.

In a speech delivered at the Oziosi academy in Naples, Francesco De Pietri defined alchemy as an altera chimera (pretentious chimera). Relying upon the authority of Gregorius Magnus, De Pietri stated that anyone who believed that transformation in nature is possible through human intervention "is an infidel and worse still a pagan". ${ }^{84}$ Directed at those "smoky and miserable" alchemists who practised chrysopoeia, De Pietri's attack on what he defined as a false art was indicative of a wider debate that condemned the transmutation of metals as a fraudulent practice.

The boundaries between religious and lay circles were often blurred and members of monastic orders frequently associated with philosophers and men of letters in a mutually shared space. As we have seen, the number of medical centres based in convents allowed members of the clergy to have access to libraries and scientific equipment which in turn enabled them to produce medical remedies. Moreover, convents often functioned as gathering

\footnotetext{
${ }^{83}$ Idem.

${ }^{84}$ Francesco De Pietri, I Problemi Accademici (Naples: Francesco Savio, 1642), 17: “infedelis est, et pagano deterior."
} 
spaces where groups from different backgrounds could conduct experiments and engage in alchemical practices. Within religious orders, alchemy was mainly employed for medical purposes. However, beyond this charitable tradition, some friars and members of the clergy also became involved in alchemical practices of a profane and less charitable nature. These included experiments concerning the transmutation of metals, designed to produce false silver and gold. In 1590, for instance, the central civil and criminal court of Naples, known as Vicaria, condemned a certain Abbot Flochari for "practising alchemy in his house with the aim of producing adulterated metal". Rather than seeking to produce real silver by alchemical means, his goal was to obtain false silver by mixing tin and antimony so as "to forge money which was then circulated in the city causing the ruin of many households". ${ }^{85}$

The transmutation of metals was also practised by members of the clergy with the aim of generating or obtaining purified gold. In 1664, Gioseffo Marini, a priest and doctor in philosophy and theology, published Breve tesoro alchimistico which contains accounts of alchemical experiments conducted in Naples. ${ }^{86}$ Some involved clergymen experimenting with the transmutation of metals. Praising the art of "the true alchemists who imitate nature by manipulating substances with admirable results", Marini recounted that Cardinal Francesco Boncompagni, Archbishop of Naples between 1626 and 1644 and a famous collector of gems, conducted an alchemical experiment in order to generate pure gold. ${ }^{87}$

The experiment possibly took place in a laboratory, because it involved luting and the use of both crucibles and a furnace. According to Marini's account, the cardinal mixed together gold, copper, cupelled mercury, borax, ammonium chloride, and powdered coal in a crucible which was then sealed with lute. Through a process of amalgamation and heating,

\footnotetext{
${ }^{85}$ Toppi, Biblioteca Napoletana, 385-6.

${ }^{86}$ Gioseffo Marini, Breve Tesoro Alchimistico (Venice: Camillo Bortoli, 1664).

${ }^{87}$ For a biographical account of Francesco Boncompagni see Umberto Coldagelli, "Francesco Boncompagni" in Dizionario Biografico degli Italiani (hereafter DBI), vol. 11, 1969, (available on http://www.treccani.it/enciclopedia/francesco-boncompagni_(Dizionario-Biografico)/).
} 
"the most noble metal purified itself finally turning into twenty-two carat gold" ${ }^{88}$ Marini also recounted a second experiment that cardinal Boncompagni conducted, this time to produce false silver. The process involved the amalgamation of tin with white tartar, ammoniac salt and other ingredients. This mixture was then heated, melted, and skimmed. Reduced to powder, the compound was subsequently mixed with tartar and then melted with ammoniac salt and iron. The final result was a "white and hard metallic substance which looked like pure silver". ${ }^{89}$ But the falsification of metals was also achieved by using the properties of some plants which, Marini recalled, had been discovered by some "brave alchemists in their experiments with wonderful results". ${ }^{90}$ Here Marini referred to the Neapolitan Theatine friar Giovanni Battista Caracciolo, a respected theologian who wrote books of sermons and texts on Christian conduct. He was also appointed as Superior at the Church of St Paul of Naples around $1654 .^{91}$ In 1653, Caracciolo published a book instructing "the temperate man" on mortification and modesty. ${ }^{92}$ In the section devoted to "subduing one's curiosity", the Theatine friar attacked the "immodest desire for scientific curiosity and experimentation". In condemning the vacuity of judicial astrology, chiromancy and metoposcopy, Caracciolo also railed against "the groundless knowledge of alchemists and chemists", ${ }^{93}$ Labelling them charlatans, he stated that alchemists appeared dirty and emaciated "because they were

\footnotetext{
${ }^{88}$ Marini, Breve Tesoro Alchimistico, 17-8.

${ }^{89}$ Marini, Breve Tesoro Alchimistico, 65-67.

${ }^{90}$ Marini, Breve Tesoro Alchimistico, 70.

${ }^{91}$ For a reference to Giovanni Battista Caracciolo as a member of the Theatine order in Naples see Marcella Campanelli, I Teatini (Rome: Edizioni di Storia e Letteratura, 1987), 388; Stefano Pepe, Le maraviglie operate da Dio. Per intercessione del B Gaetano Tiene Fondatore de Cherici Regol. (Rome: Ignatio de' Lazari, 1657), 403.

${ }^{92}$ Giovanni Battista Caracciolo, Della Mortificatione e Modestia. Tanto nell'interno, quanto nell'esterno Dell'Huomo Temperato (Naples: Camillo Cavallo, 1653), Preface.

${ }^{93}$ Caracciolo, Della Mortificatione, 190.
} 
relentlessly exposed to smoke and fire, silver, arsenic, and the smell of charcoal". 94 Alchemy was, he concluded, ultimately "a sacrilegious and vain art". 95

Beyond the censored world of religious printed propaganda, however, Caracciolo showed a different attitude towards alchemy. Described by Marini as a skilled practitioner, he indeed experimented with metals and plants. Marini also described him as the discoverer of some virtues of plants and minerals which the friar allegedly disclosed during his alchemical experiments. Specifically, Marini recounted three experiments conducted by Caracciolo with the aim of freezing mercury and producing false gold and silver. The method used in these experiments involved the use of vegetal substances in the form of powder or liquid extract to be mixed with mercury through a process involving heating and amalgamation. To falsify gold and silver, Caracciolo again relied on a mixture of powdered plants and oil of putrefied worms to be heated with tin and iron in order to generate "a kind of matter that looks like gold or silver". 96

The cases of Boncompagni and Caracciolo show that, away from the public eye and beyond the publicly visible work of medical alchemy, high-ranking clergymen and members of the religious orders were fascinated by the other possibilities alchemy had to offer. Boncompagni and Caracciolo's familiarity with laboratory procedures such as elaboration, distillation, dealbation of minerals, heating, contrition, and liquefaction, to name but a few, also tells us that in Naples a variety of alchemical practices were performed. As Cardinal Boncompagni "successfully" experienced, alchemy had the power to fulfil an ultimate dream: generate pure gold through human intervention. In the case of Caracciolo, alchemy proved to be equally effective in producing fake precious metals. As analysed by Neil Tarrant in his contribution to this issue, in at least some Thomistic and Augustinian traditions natural

\footnotetext{
${ }^{94}$ Caracciolo, Della Mortificatione, 191.

${ }^{95}$ Caracciolo, Della Mortificatione, 192.

${ }^{96}$ Marini, Breve Tesoro Alchimistico, 74-78.
} 
alchemy - including chrysopoeia - was considered to be a legitimate art so long as its practitioners did not resort to the invocation of demons. Hence, although by the sixteenth century the practice of gold-making was strongly condemned as a sophistic and fraudulent art in Civil and Canonical law, it was not necessarily regarded as heretical. ${ }^{97}$ In other words, the debate on the legitimacy of alchemy centred on human manipulation of nature rather than the practice of transmuting metals.

Within the Church the experiments conducted by Cardinal Boncompagni and friar Caracciolo pushed the boundaries of orthodox alchemy. Their interest in conducting experiments aimed at producing fake metals or purer forms of gold also tells us that within Neapolitan religious circles alchemy developed through different pathways. In this context, affluent private houses and the protected walls of some Neapolitan convents became venues where members of religious orders practised chrysopoeia. As we have seen, figures like Abbot Flochari, Cardinal Boncompagni and friar Caracciolo saw in alchemy a tool for financial gain or simply a fascinating game for which they were all prepared to circumvent the divine order of nature. Conversely, for figures like friar d'Eremita alchemy was an instrument through which God had enabled pious practitioners to disclose the occult properties of nature with the aim of alleviating human sufferings.

\section{Conclusion}

\footnotetext{
${ }^{97}$ Evangelista Quattrami, La Vera Dichiaratione di Tutte le Metafore, Similitudini, \& Enimmi de gl'Antichi Filosofi Alchimisti... Ove con un breve discorso della generatione de i metalli, quasi tutte l'opere di natura, secondo i principij della Filosofia, si mostra l'errore, \& l'ignoranza (per non dir l'inganno) di tutti gl'Alchimisti Moderni...Per Frate Evangelista Quattrami da Gubbio dell'ordine Eremitano di S. Agostino, Semplicista, \& distillatore dell'Illustrissi. \& Reverendissimo Sig. Card. d'Este (Rome: Vincenzo Accolti, 1587). See also Tarrant's analysis in this issue of the papal bull 'Spondent quas non exhibent' issued by John XXII in 1317 which banned the fraudulent production of metals.
} 
This essay has analysed the development of alchemy in early modern Neapolitan religious orders. In a city that was one of the leading centres of learning in early modern Europe, some convents became known as research centres where alchemical experimentation was conducted. The brief overview of the number of facilities available in certain Neapolitan convents has shown that friars had access to libraries and well-equipped laboratories. The milieu that flourished in the convent of Santa Caterina a Formello, for instance, also indicates that friars did not work in isolation. As we have seen, figures such as Friar Donato d'Eremita were admitted to important academies of science and networked with scholars such as Della Porta and Imperato who had both facilitated the Neapolitan circulation of Paracelsian ideas. It is also well known that Della Porta's research had been often impeded by close inspection by the Roman Inquisition. D'Eremita's studies on disciplines such as botany, mineralogy, metallurgy, and gemmology were also paired with an empirical approach that centralised the role of alchemical experimentation for medical purposes. As we have seen, the friar worked assiduously on improving the distillation process in order to perfect his elixir for the benefit of all. Analysed from this angle, d'Eremita's case can therefore be located within a wider trend in early modern European alchemical research that, as recently analysed by William Newman and Lawrence Principe, merged the medieval alchemical tradition with the iatrochemistry of Paracelsus and his followers. ${ }^{98}$

Conversely, the case studies analysed in this essay have shown that in Naples religious orders did not look at alchemy from a common angle and with a common aim. The stories of Abbot Flocari, Cardinal Boncompagni and friar Caracciolo have highlighted that some members of Neapolitan religious orders engaged with alchemy for reasons that were far from having a religious intent. The relative freedom that some clergymen enjoyed in conducting alchemical experiments concerned with chrysopoeia also raises questions on the

\footnotetext{
${ }^{98}$ William R. Newman and Lawrence M. Principe eds., Alchemy tried in the fire: Starkey, Boyle, and the fate of Helmontian Chymistry (Chicago and London: Chicago University Press, 2014), 38.
} 
extent to which central ecclesiastical authorities exercised stringent control on the life of religious orders.

Beyond their noble or profane ends, however, some Neapolitan clergymen became expert practitioners in the alchemical art. In this context, their research contributed - perhaps unsurprisingly - to the European development of pharmaceutical research. As we have seen, some friar-practitioners also benefitted from the financial support available within their convents. For examples, with the money he received from the prior of Santa Caterina a Formello, d'Eremita was able to set up an important museum, acquire a large number of books, and enlarge the convent's herb garden with species from the New World. Moreover, d'Eremita established a well-equipped laboratory that enabled him to conduct alchemical experiments in order to produce the perfect elixir of life. D'Eremita's commitment to research also made him one of the most important practitioners of his time. Yet his deep knowledge was the cause of his death. Whether a natural or chemically prepared substance, it is not unreasonable to suggest that friar d'Eremita took from the laboratory where he had worked strenuously to produce an antidote for longevity the substance that, in the isolation of his prison, he swallowed to end his life.

\section{$\underline{\text { Acknowledgements }}$}

I would like to take this opportunity to thank Andrew Campbell, Neil Tarrant, Peter Murray Jones and Justin Rivest for their friendship and academic rigour. A special thanks goes to Prof. Bruce Moran and Ariel Hessayon for their guidance and constructive criticism. Finally, I am grateful to the two anonymous readers for their invaluable feedback. Unless otherwise stated, all translations are my own. I alone am responsible for any mistakes or shortcomings. 
Illustrations 


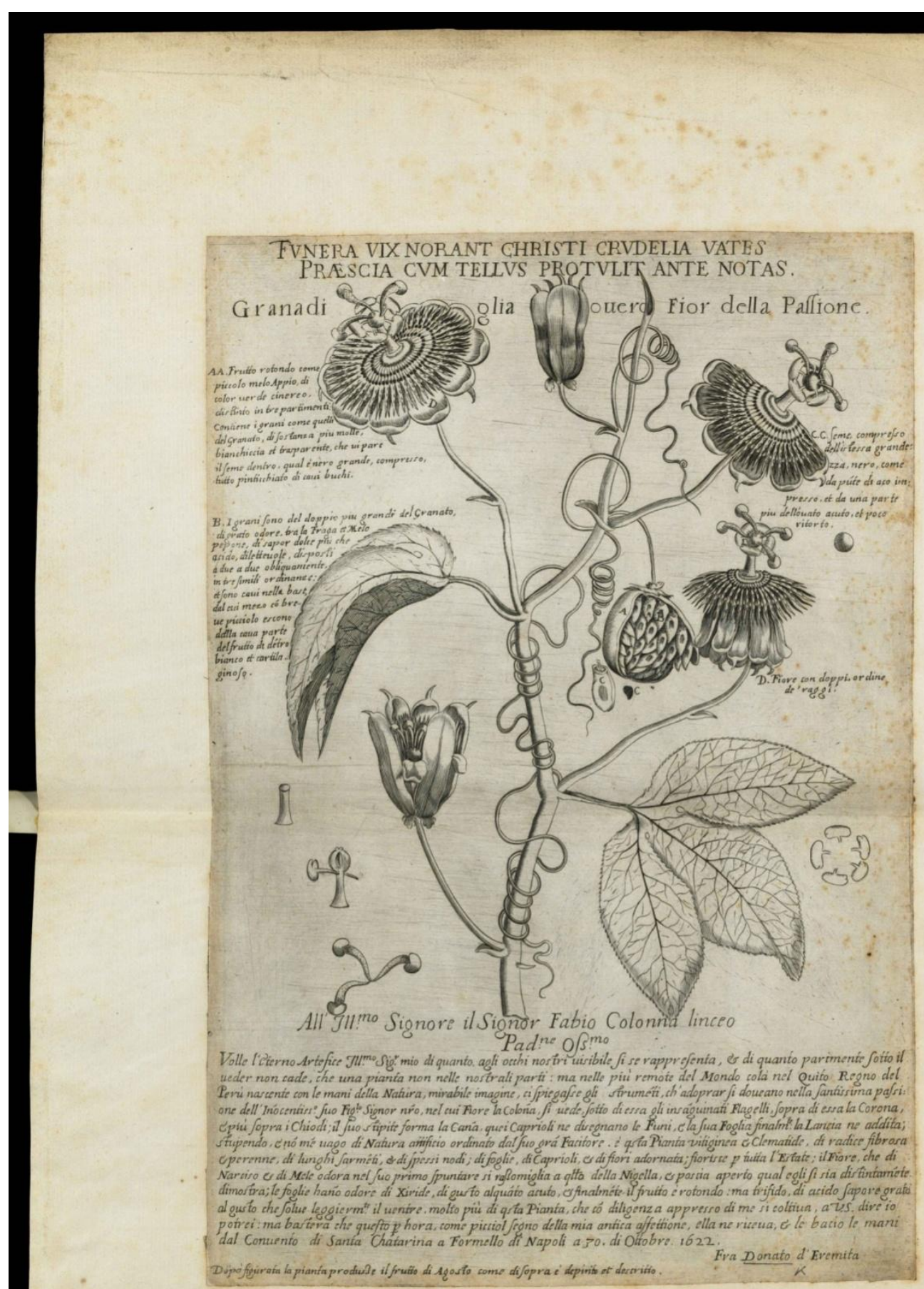


Figure 1, Donato d'Eremita, Engraving of Passiflora with dedication to Fabio Colonna. By permission of The Natural History Museum Library, London, Special Collections. Shelfmark: SB 582.4P74.RAS.F.CAT. UNIT, Plate 4. 


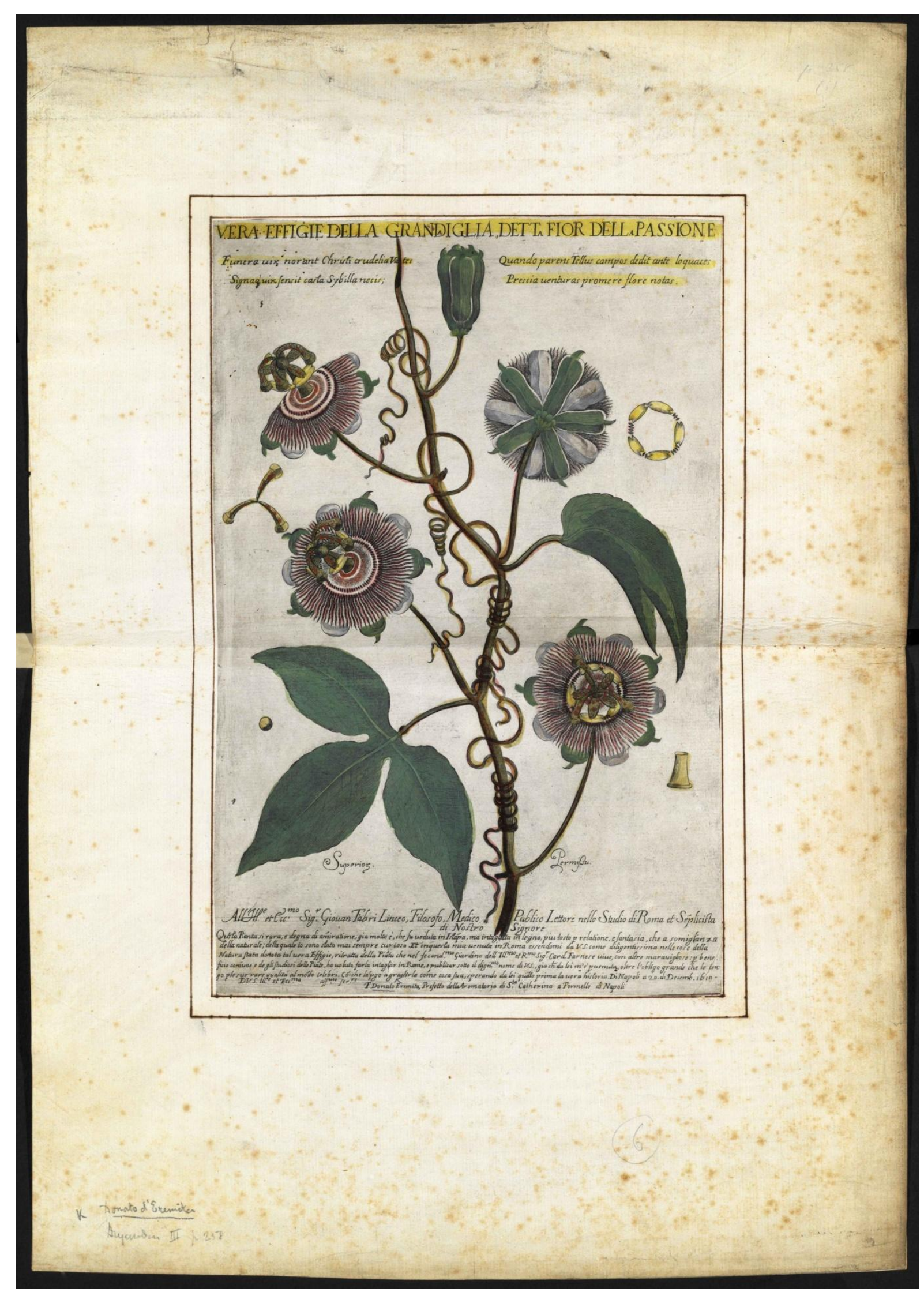


Figure 2, Donato d'Eremita, Engraving of Passiflora with dedication to Johann Faber. By permission of The Natural History Museum Library, London, Special Collections. Shelfmark: SB 582.4P74.RAS.F.CAT. UNIT, Plate 6. 


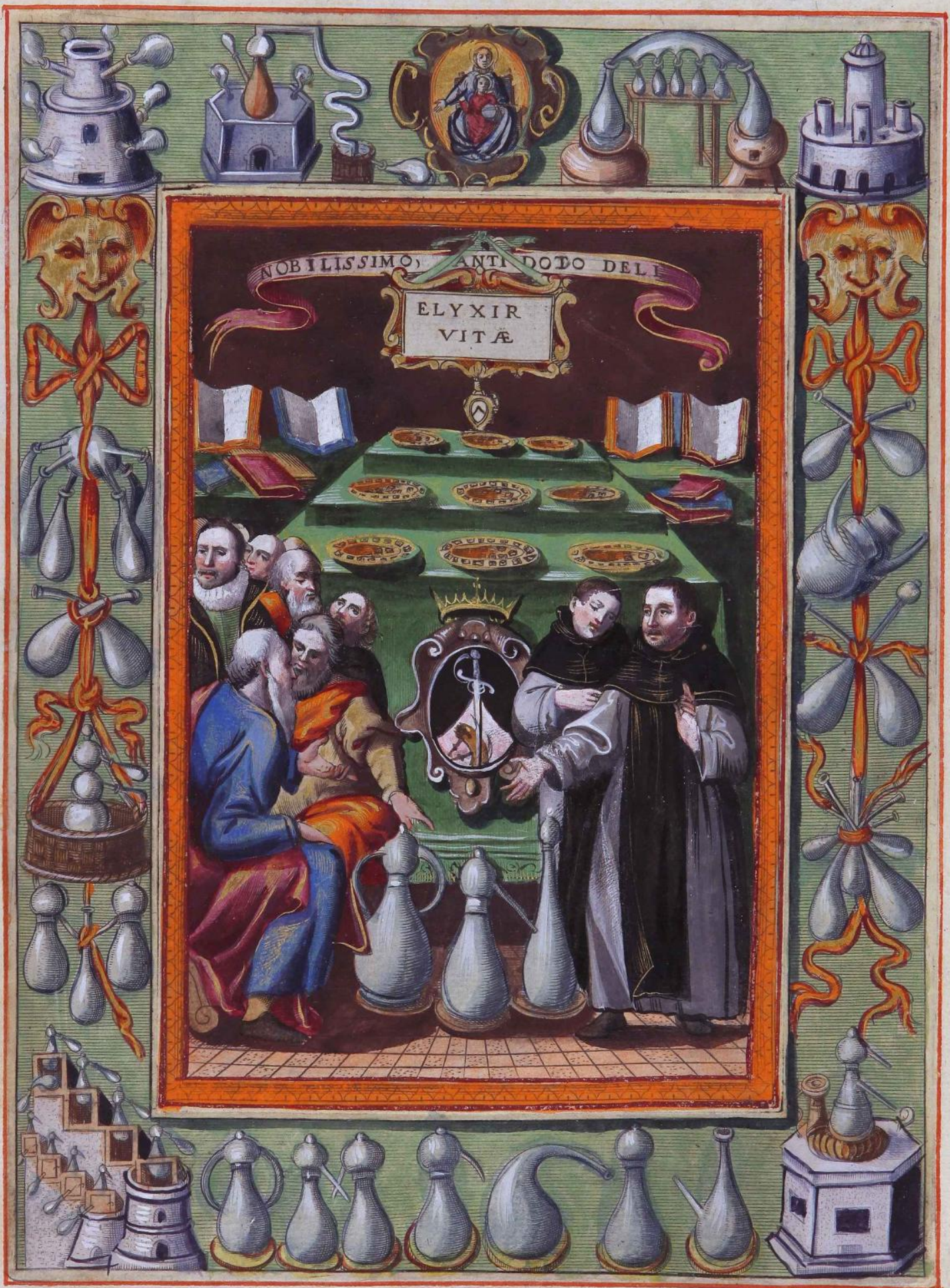


Figure 3, Donato d'Eremita, Elixir Vitae (Naples: Secondino Roncagliolo, 1624). By permission of The National Library, Florence, Special Collections. Shelfmark:

MAGL.1.2.149, unnumbered page. 


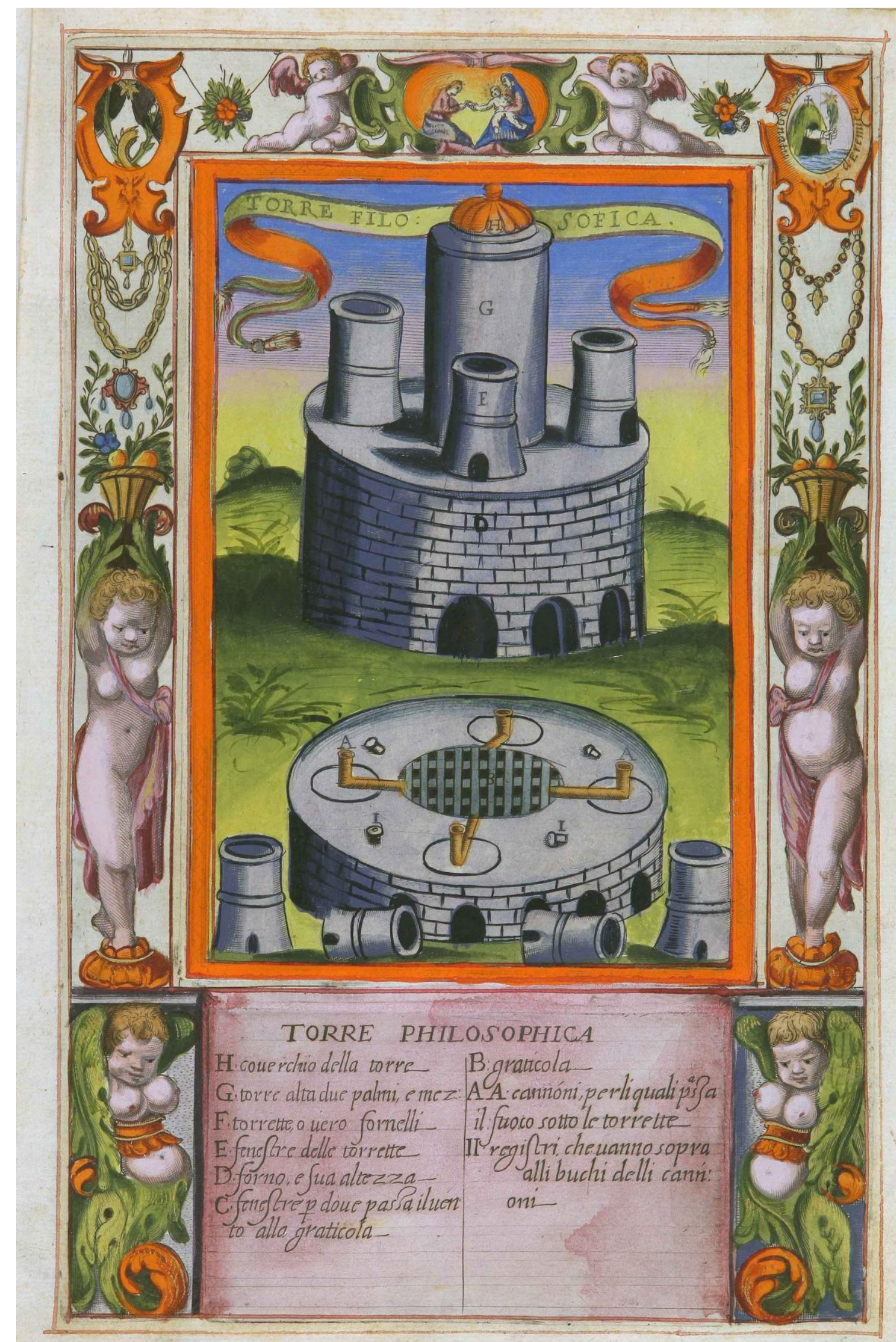


Figure 4, Donato d'Eremita, Elixir Vitae (Naples: Secondino Roncagliolo, 1624)

Philosophical Tower. By permission of The National Library, Florence, Special Collections.

Shelfmark: MAGL.1.2.149, unnumbered page. 


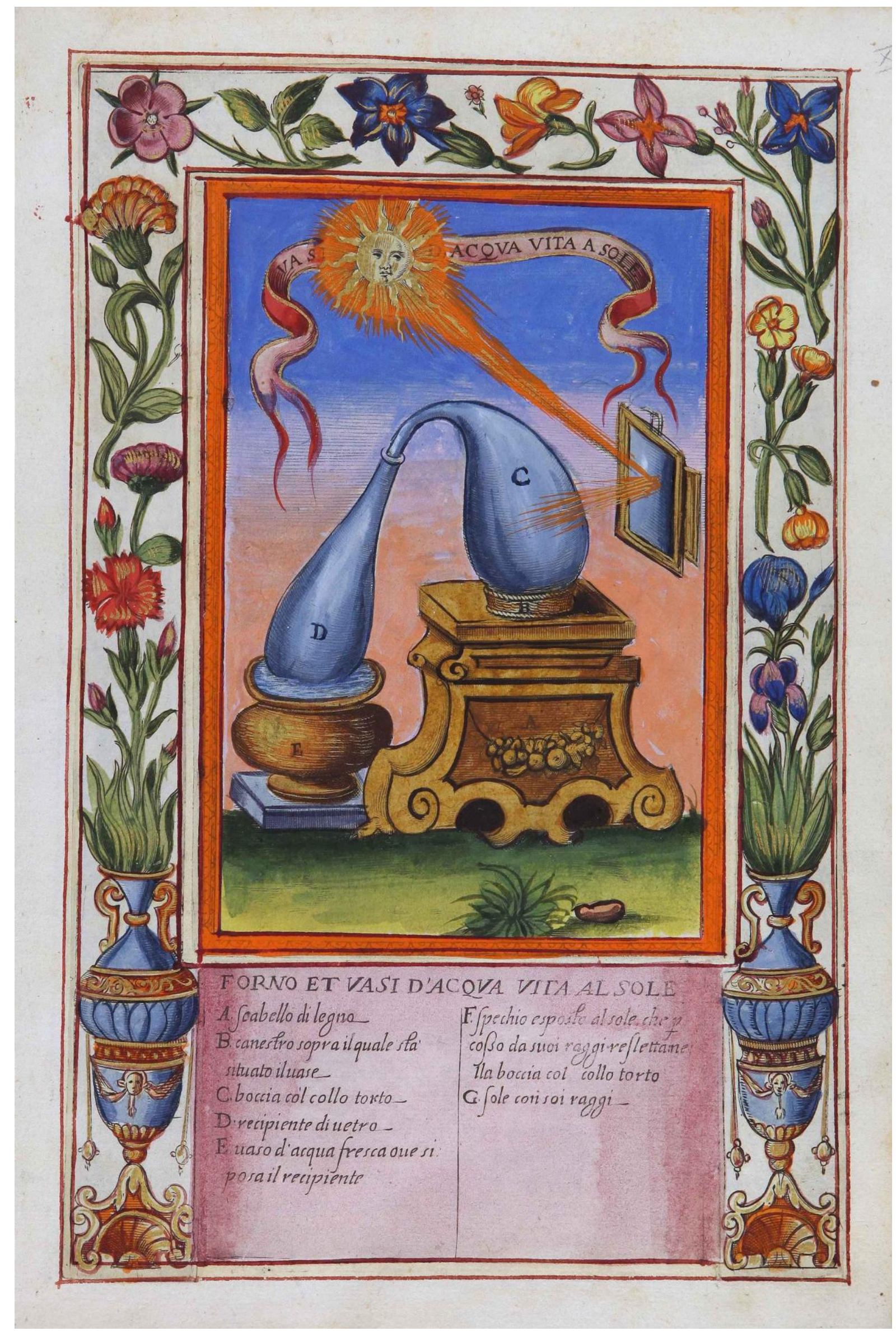


Figure 5, Donato d'Eremita, Elixir Vitae (Naples: Secondino Roncagliolo, 1624) Furnace and vases of Aqua Vitae in the sun. By permission of The National Library, Florence, Special Collections. Shelfmark: MAGL.1.2.149, unnumbered page. 


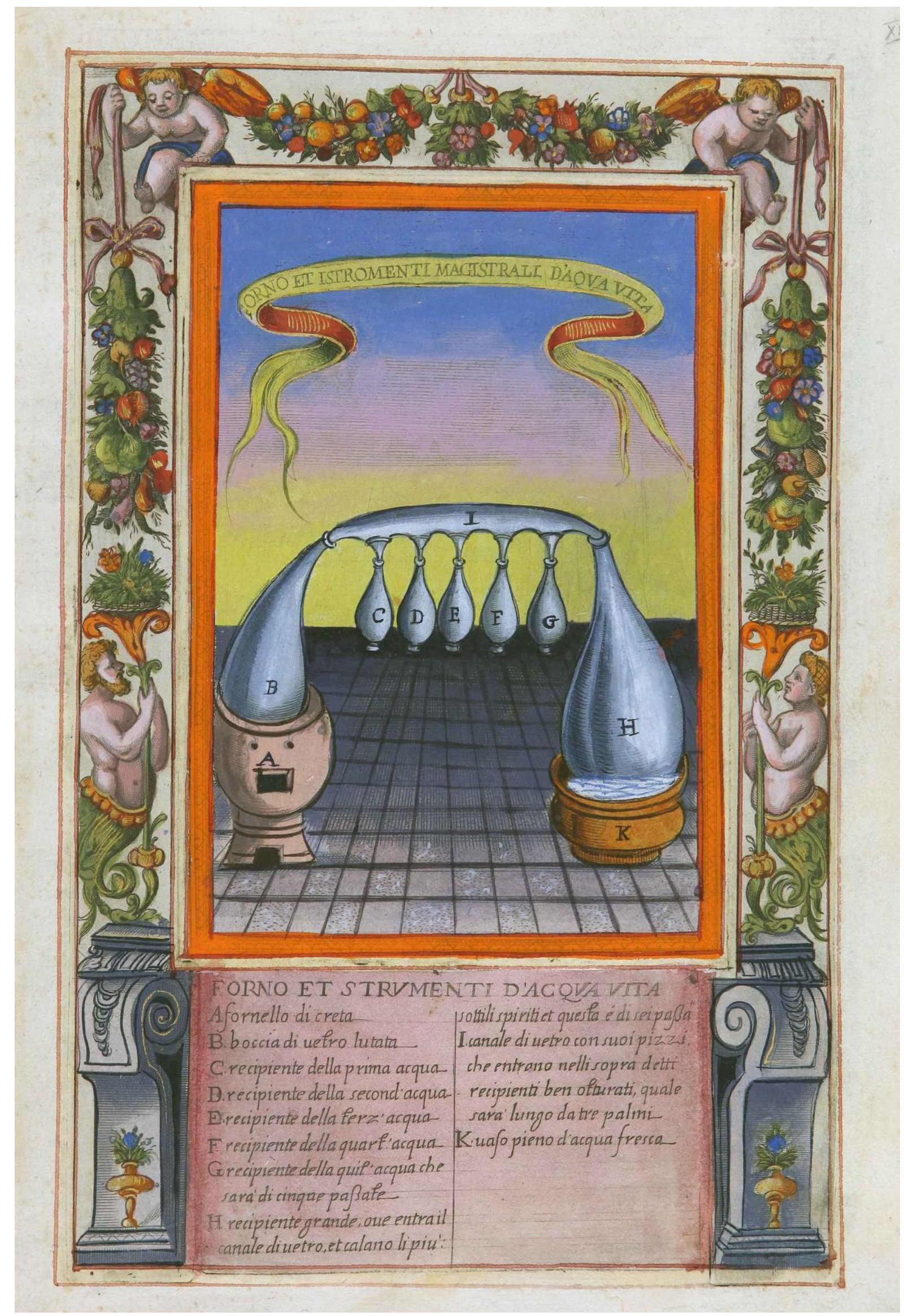


Figure 6, Donato d'Eremita, Elixir Vitae (Naples: Secondino Roncagliolo, 1624) Furnace and instruments for Aqua Vitae. By permission of The National Library, Florence, Special Collections. Shelfmark: MAGL.1.2.149, unnumbered page.

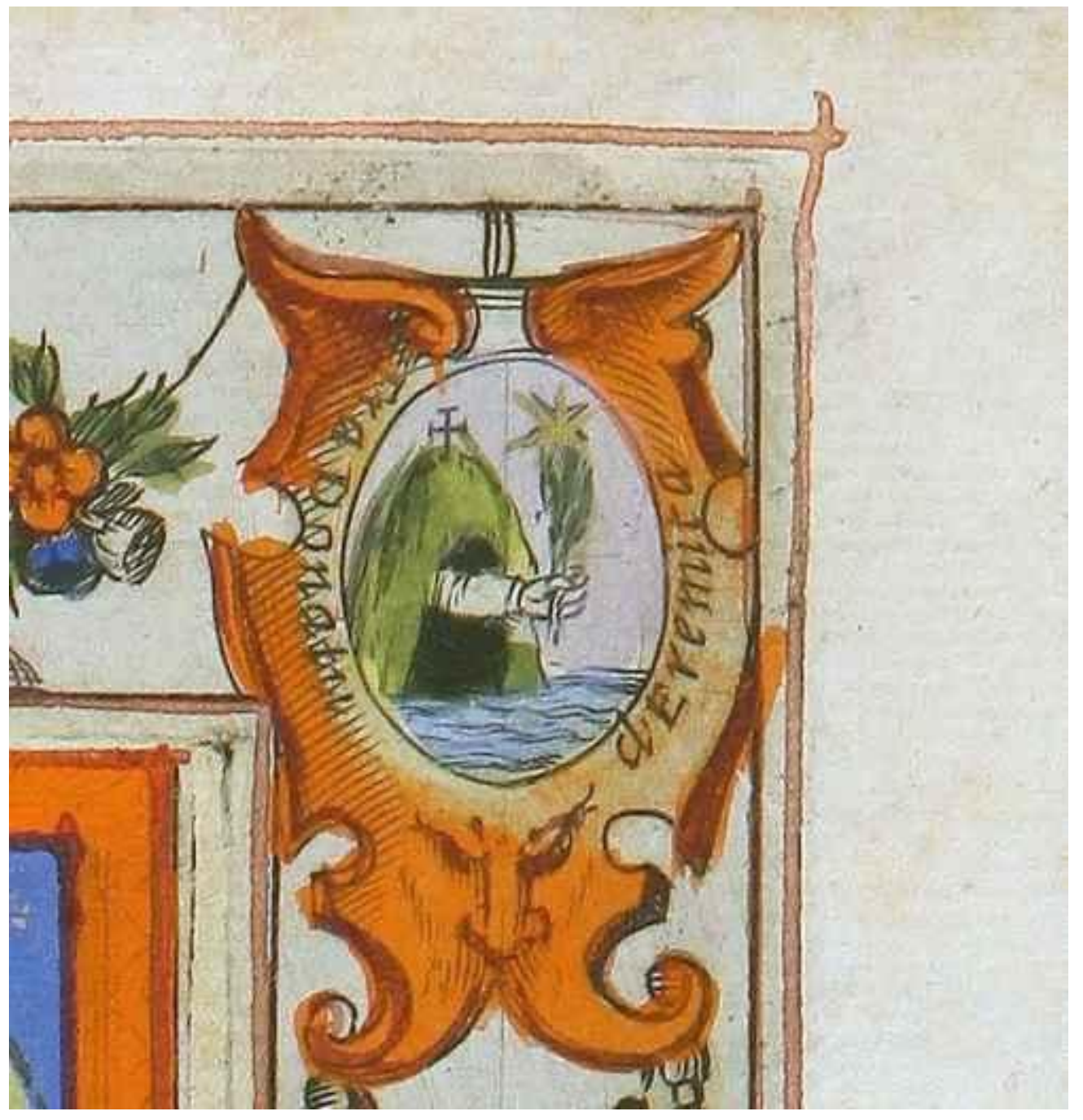

Figure 7, Donato d'Eremita, Elixir Vitae (Naples: Secondino Roncagliolo, 1624) Detail of Donato d'Eremita's personal emblem. By permission of The National Library, Florence, Special Collections. Shelfmark: MAGL.1.2.149, unnumbered page. 
Lorenza Gianfrancesco is a Senior Lecturer in Early Modern History at the University of Chichester. She has been part of the research team working on a project dealing with Italian academies in early modern Italy funded by the Arts and Humanities Research Council (italianacademies.org). She has published articles and essays on Vesuvius, academies and science, with a particular focus on early modern Naples. Lorenza is co-editor of Napoli e il Gigante. Il Vesuvio tra immagine, scrittura e memoria (Rubbettino, 2014), Disaster Narratives in Early Modern Naples. Politics, Communication and Culture (Viella, 2018), and the author of a forthcoming monograph entitled Academies and the urban sphere in early modern Naples . 